\title{
Um exame crítico dos contos de Taunay
}

\begin{abstract}
A ssocia-SE o nome de Alfredo d'Escragnolle Taunay, para quasi $A$ todos, com Inocência, um dos romances mais famosos dos que foram escritos na América Latina, e la Retraite de Laguna, a história épica de uma campanha árdua que se realizou durante a guerra do Brasil com o Paraguay. Estas duas obras são, sem dúvida, os produtos de mais fama que sairam da pena de Taunay, porém, êste mesmo homem teve uma produção literária que foi positivamente prodigiosa. Entre essa produção figuraram-se alguns dos melhores contos escritos no Brasil durante o século xIx. Taunay publicou três volumes de contos, e também escreveu duas fantasias líricas, que foram incluidas em Céus e terras do Brasil. Tôdas estas obras têm recebido pouca atenção crítica, menos a de García Mérou, quem louvou a "sinceridad de la impresión poética, la verdad del paisaje, la novedad del exoticismo" das Históriàs brazileiras, ${ }^{1}$ e a de Driver, quem atribúa, erroneamente, os contos "Ierecê a Guaná" e "Camiran a Kinikináo" a Céus e terras do Brasil, e não a Histórias brazileiras. ${ }^{2}$
\end{abstract}

\section{Histórias brazileiras}

Em Histórias brazileiras, publicado sob o pseudónimo "Sylvio Dinarte," em 1874, Taunay revela uma capacidade de fazer viverem os personagens, com um toque destro e seguro. Não faz êle, em nenhum dos contos, desenvolvimentos elaborados de caráter, mas antes dá uma caraterização da figura central, subordinando as outras.

Descreve-se detalhadamente, em "Ierecê a Guaná," sómente Ierecê, a moça india que amou Alberto Monteiro e que morreu quando 
êste a deixou. Apesar de alguns defeitos, era a de Ierecê uma beleza extraordinária, e o seu temperamento era um de "muita brandura, tristeza e alguma curiosidade." 3

Pacalalá, de "Camiran a Kinikináo," vê-se no papel de um jovem forte, de uma honestidade absoluta, um líder nato, e de bravura e coragem excepcionais. Há, de sua mãe, Camiran, sómente uma vista breve, lamentando tão amargamente a morte de filho, que não pôde participar-se na orgia tradicional de luto.

Padre Monte, o protagonista de "O Vigário das Dôres," é o personagem mais cuidadosamente descrito do volume, magnificamente pintado na sua luta entre as suas dúvidas e tentações. humanas, e o seu desejo ardente de experimentar o fervor místico pelo que suspirava e que, culpando-se, achava que devia sentir. Feito padre por gratidão a uns padres de São Paulo que o haviam educado e instruido, era êle venerado de todos, e fazia caridade com alegria. Porém, sabia êle que lhe faltava aquele fogo sagrado que the parecia indispensável ao cumprimento da missão que as circunstâncias the haviam impôsto. Provou a oração e a contemplação de textos sagrados, mas ainda sentia dúvidas que não podia conquistar. Sentia-se rebelde, e, sendo sincero, convenceu-se de que era pecador - especialmente na ocasião em que foi sómente um desmáio que lhe impediu de ir ter com uma prostituta cujos belos olhos êle notou. Desesperado, o Padre Monte aceitou um posto em Goyaz, onde se aprofondou num torpor espiritual, ao perceber que os seus esforços em prol do progresso religioso do seu rebanho apático não tiveram fruto.

Um dia um tropeiro deixou com o Padre Monte um pacóte de livros, não tendo achado o destinatário dos livros. O prelado não abriu o vulto, até que um cupim apareceu, dando-lhe assim razão de "salvar" os livros. Nunca antes tinha lido um.romance, e Don Quijote, que estava entre os volumes, lhe encantou por mezes seguidos, tornando-se um "bálsamo para a tristeza e consciência da solidão." 4 Finalmente, o padre caitu enfermo, teve um sonho que the causou temor pela sorte de sua alma, e ao restabelecer-se sentiu a inspiração que tanto havia ambicionado.

"Juca o tropeiro" tem pouco desenvolvimento de personagem. Juca era um moço típicamente alegre e jovial, até o final catastrófico das suas relações com Babita, a qual casou-se com outro durante a ausência prolongado d'aquêle, no serviço militar. 
O interêsse principal dos contos consiste na narração. Existe pouco esforço evidente de impressionar com o estilo. Há, verdade, algumas passagens que parecem algo forçadas e bombásticas: e. g., a apresentação de Júlio Freitas a Alberto Monteiro ; ${ }^{5}$ a declaração de Júlio a Alberto quando êste ficou doente: "Você não póde ... continuar... sem incorrer na pécha de imprudente "" e a descrição da prostituta que atraiu Padre Monte, a qual "Era uma d'essas infelizes que desfolhão as corollas de sua belleza ao sôpro gélido da prostituição." 7 Esta expressão constrangida, não obstante, tem sómente uma importância menor ao contrastar-se com a força verdadeira e excelente encontrada na maior parte do volume.

Algumas passagens evocam uma pintura vivida da natureza observada. Há uma excelente descrição artística da paisagem entre Miranda e Nioac. ${ }^{8}$ A cor tem um papel importante na pintura de uma noite de luar. ${ }^{9} \mathrm{O}$ som figura: "embóra o pio aterrado do jáo acordasse melancólicos os echos da floresta, embóra o bacuráo atirasse aos ares as plangentes notas da áspera garganta;" 10 e quando Padre Monte lia o seu breviário, pela noite: "Fóra os grilos chiavão estridulos, e os sapos com um coachar sonóro formavão monótona orchestra." 11

Várias passagens merecem atenção do ponto de vista de técnica, por descrição eficaz, ou por fraseologia gráfica. Um exemplo disto é a despedida de Alberto e Ierecê. ${ }^{12}$ Além disso, em "Camiran a Kinikináo," mortos os defensores de Dourados: "D'ahi a pouco era arreada a bandeira..., mas ella desceu com ufania como bandeira de victória e... parecia enrubescer de orgulho," do sangue dos mortos. ${ }^{13}$ "Juca o tropeiro" é narrado como se falasse um sertanejo, com harmonia entre a parte narrativa e a atmosfera geral do conto: e. g., a apresentação do cabo de esquadra, quem, "já com algumas garrafas de cerveja no bucho, esbugalhava uns olhos muito grandes e fazia com os dentes tal barulho que semelhava não um caiteté, mas uma vara inteira de porcos." ${ }^{14} \mathrm{E}$ Juca, antes da guerra, gostava de cantar, "contente como um ricaço e cheio de si como se tivesse o rei na barriga." 15

A caraterística mais saliente de Histórias brazileiras é o ambiente completamente realístico e local dos contos. Alguns são imaginativos e originais, tais como "Juca o tropeiro" e "O Vigário das Dôres," e outros são algo mais prosaicos, porém, todos têm a feição 
comum de acentuar a cor local e os costumes, levando Driver a chamar Taunay "the ablest regionalist of his time." 16 Para Driver, "Ierecê a Guaná" sugere Iracema, "in its portrayal of the tragic union of the two races. Taunay's feeling for nature and the Indians are like Alencar's. But he is not extreme in his idealization." 17 Porém, em Histórias brazileiras, Taunay dedica relativamente pouca atenção à natureza. Seu sentimento pelo índio não se parece com o de Alencar, que eu possa perceber, e êle não idealiza. Ierecê, por exemplo, vê-se bela, mas bela apesar de certos defeitos evidentes e inerentes. $E$ verdade que a intriga do conto tem certa semelhança estrutural à de Iracema, mas não me parece que haja mais nada.

Grande parte do que García Mérou chama "exoticismo," ${ }^{18} \mathrm{em}$ "Ierecê a Guaná" e "Camiran a Kinikináo" é baseado em observações feitas pelo Visconde durante a expedição a Matto Grosso. Achamse certas notas feitas por êle durante aquela saida abortiva, cujo ponto climático foi a retirada da Laguna, em Entre os nossos índios, publicado em 1931 por Affonso d'E. Taunay. Este declara, no prefácio, que achou em grande desordem as notas de seu pai, mas que, a respeito das de que se trata: "Seu autor as destinava, quer me parecer, a um estudo sobre os índios que em Matto Grosso frequentara ou a alguns capítulos de sua obra inacabada $A$ cidade le Matto Grosso." 19 meu parecer, que Taunay já tinha empregado estas notas em Histórias brazileiras e em Scenas de viagem. Os vestimentos e a ceremônia do velho Morevi, o "padre" de "Ierecê a Guaná," constam um emprêgo patente de uma seção de Entre os nossos indios e de Scenas de viagem. ${ }^{20}$ "Camiran a Kinikináo" é pouco mais do que uma paráfrase das notas sôbre Pacalalá de Entre os nossos indios; com a exceção do enterro de Pacalalá e a morte de Camiran, é uma versão pouco elaborada dos mesmos acontecimentos. $\mathrm{O}$ conto é quasi todo leal à verdade, ainda que bastante interessante e bem narrado para ser o produto de uma imaginação fecunda. Uma comparação de algumas passagens demostrará que "Camiran a Kinikináo" é mais ou menos nova versão de certas partes de Entre os nossos indios. A descrição de Pacalalá é parecida. ${ }^{21}$ A relação de um exemplo da energia e honestidade de Pacalalá tem muita semelhança. ${ }^{22} \mathrm{O}$ acolhimentos pelos índios da notícia da morte de Pacalalá é contado, nos dois volumes, em quasi a mesma maneira. ${ }^{23} \mathrm{~A}$ 
dor de Camiran, ao saber que. seu filho morreu, é narrada nos mesmos termos. 24

Outra fase do ambiente realístico de Histórias brazileiras, ainda que de menor importância em alguns dos contos, é o emprêgo de linguagem e de expressões coloquiais. Há, em "Ierecê a Guaná," algumas frases no dialeto Chané, mas é únicamente em lugares isolados que se usam "brasileirismos," como no modo de falar do soldado que acompanhou Alberto. ${ }^{25}$ Em "Camiran a Kinikináo" há poucos coloquialismos, vista a falta de diálogo. "O Vigário das Dôres" os tem sómente na fala do tropeiro que deixou os livros com Padre Monte. "Juca o tropeiro", porém, é cheio de expressão coloquial, tanto no diálog̀o como na narração, e uma parte relativamente pequena está impressa em itálico - isto contra o costume de Taunay. ${ }^{26}$ A verossimilhança aparente dêste conto é acentuada por um prefácio, onde o autor anuncia que êle obteve os fatos de um antigo sargento do exército, e que tentou retirar "loucuções chulas e sertanejas," mas, todavia, "desejando conservar ainda um quê da ingênua, mas pitoresca expressão do narrador." 27

Sustenta-se ainda mais o ambiente realístico com notas numerosas de descrição ou de definição, e. g., sôbre o nome de um distrito; sôbre o termo "lavrado;" sôbre o fato de que o corpo de Pacalalá não se decompôs; sôbre a alcunha "Dona Cula," etc. ${ }^{28}$

Existem, no volume, certo número de digressôes, porém, não são tão prolongadas que ofendam ao leitor. Variam-se de comentários sôbre costumes, a declarações morais e políticas, e. g., sôbre a gula dos índios; sôbre a pobreza da província de Goyaz; sôbre as razões peła falta de energia de Padre Monte; sôbre a alegria de recuperar-se de uma doença grave. ${ }^{29}$ Não digressiva, mas altamente inspiracional, é a decisão final de Padre Monte, de ir para a floresta afim de predicar aos aborigenes.

Dos quatro contos de Histórias brazileiras, "Ierecê a Guaná" e "Camiran a Kinikináo," particularmente, foram escritos com uma atmosfera de regionalismo autêntico, e dando realce aos costumes e práticas da região. "O Vigário das Dôres" dá evidências de ingenuidade, descrevendo o conflito d'alma de um homem que logrou, finalmente, alcançar um alto nivel ascético, se não mistico, de fervor religioso, desaforando as exigências da carne e as nuvens de dúvidas. "Juca o tropeiro" é encantador, humoristico ao fundo, mas ainda 
trágico no espetáculo patético de uma alma simples e confiada que se tornou grande na sua habilidade de perdoar uma injúria grave. $O$ conto inteiro tem uma harmonia completa entre o estilo e o assunto.

\section{Narrativas militares}

O volume Narrativas militares foi publicado em 1878, com o sub-titulo "Scenas e typos," sob o pseudónimo "Silvio Dinarte," mas também com os iniciais do autor, "A. d'E. T." Nunca foi republicado. Também não foi bem acolhido pelo público, até durante a vida de Taunay. Isto se percebe em notas suas, escritas entre 1894 e 1898 e publicadas por seu filho em 1920 com o titulo Dias de guerra $e$ de sertão. Nessas notas mencionou "o meu livro NaRRativas militares, ... que tem cunho verdadeiramente profissional e [que] há de um dia ser devidamente apreciado." " 30 Há muitos detalhes que não teriam intêsse para quem não estivesse devotado a assuntos militares. Poderia ser essa a razão porque os leitores preferiram Céus e terras do Brasil, publicado em 1882, que incorporou algumas das passagens de interêsse mais geral encontradas em Narrativas militares, e que teve oito edições de um total de 20.000 exemplares até 1929 .

Visto que "O irmão," a primera seleção do volume, é uma relação exata dos acontecimentos que antecederam o começo de la Retraite de Laguna de Taunay, não há personagens principais. Há, não obstante, uma enumeração das habilidades de um "camarada" típico; êste é o compaheiro e guia fiel que atende solícitamente seu amo, que é perito em viajar pelo deserto, e que é capaz de confrontar qualquer contingência que sobrevenha. Repete-se literalmente esta relação, com a exceção de umas poucas frases, em Céus e terras do Brasil. ${ }^{31}$

Acham-se, em "A vingança de um recruta," vários personagens louváveis. Tonico, o protagonista, revela-se, contando a história, como um moço patriótico, sincero, mas mal instruido e gárrulo, que tem a atitude típica do sertanejo com respeito à honra pessoal, i. è., qualquer injúria póde ser aceita filosóficamente, menos uma bofetada. Esta tem que ser paga com sangue. Dona Thomasia, que parece brevemente, é engraçadamente vívida como a velha feia que, quando seu sobrinho se engajou no exército, decidiu mudar-se para a cidade, onde não correria o perigo de ser desrespeitada. O sargento Marçal 
era um velho militar, severo, belicoso, e "com cara de poucos amigos," que descarregou seu ressentimento, por não ter sido promovido, sôbre os seus subordinados.

O capitão Pitaluga, de "O capitão caipora," consta um estudo interessante de uma pessôa pontual e tacanha. Enviava constantemente comunicações ao governo, escritas sôbre uma variedade de assuntos. Uma vez pediu uma indenização de 543 réis, e outra, queixou 'com éxito contra o uso de botões de massa a favor dos de metal, nos uniformes - mas até êste triunfo não lhe ganhou a desejada promoção. O major Fonseca era o amigo e colega de Pitaluga. De voz estridente, sempre precipitava-se de um lado para outro, tinha controvérsias com Pitaluga e ameaçava, sem razão, os soldados. Porém, sendo seu coração contrário a seu temperamento, não levava a cabo as suas ameaças.

Em "Um dia de paixão," não existe nenhum personagem que mereça atenção. Os personagens são tão superficiais, quanto o conto.

Há, em “Tio Hilário," representação de caráter, de alta qualidade. Hilário, o amimado de sua mãe, ao ter que morar na guarnição. militar, tentou reconciliar-se a ser o alvo dos gracejos de seus companheiros. Não podendo conquistar certa modéstia e timidez, que o tornaram vulnerável, sofreu o melhor que pôde tudo o que the foi desagradável. Compreendeu que não estava doado de temperamento de soldado. Receiava chamar a deshonra para o seu nome de família, porque amava a filha de um militar. Ao fim, seguindo o conselho do tenente Peres, pediu ser transferido para a zona de combate, onde conduziu-se corajosamente. O pai de Hilário é bem retratado; velho guerreiro reformado, cheio de ambição por seu filho, mas medroso ao ter êste que confrontar o perigo. $O$ velho Peres é uma criação feliz, talvez a melhor do conto. O companheiro inseparável do pai de Hilário, era um tenente reformado que tinha deixado uma perna no campo de batalha, e por isso usava uma de madeira. Do velhinho jorravam discursos fogosos, confundindo-se engraçadamente generais e almirantes: "D. Pedro Cevallos, almirante em terra e general no mar ... Não, com mil demônios ... é o contrário... Não me perturbem!" 32 Via tudo do ponto de vista do soldado, porém, sob o seu casco externo tinha o coração sentimental e simpático.

A ficção desta coleção é excelente, com a exceção de "Um dia de paixão," que é superficial e exagerado tanto nos outros aspetos, 
quanto na trama. Num prefácio, Eugênio, escrevendo uma carta a "Sílvio," menciona "essa leveza de estylo que comportava o caso, êsse apuro gracioso, essa coreção de phrase,... êsse esmero, em fim," ${ }^{33}$ que se desejam ao contar uma história. Apesar dessas ambições anunciadas, a leveza de estilo fica esforçada ao ponto da insipidez; a desejada delicadeza torna-se frívola; a correção de frase é muito trivial para impressionar ao leitor, e o ansiado estilo polido é frágil e monótono. Exemplos típicos do supra-mencionado são a "conversação" entre a "botina Meliès" de Eugênio e o "sapatinho assetinado" de Adélia, e a narração da entrevista nocturna entre os dois amantes. ${ }^{34}$

Há, do outro lado, verdadeiro mérito em outras partes do volume. Vêm-se, em "O irmão," vívidas descrições da natureza, observada pelo autor, e. g., uma vista formosa do Rio Aquidauana, a qual se repete quasi palabra por palabra, em Céus e terras do Brasil. ${ }^{35} \mathrm{Re}-$ pete-se também, no mesmo livro, ainda que menos fielmente, a descrição notável de uma tempestade. ${ }^{36}$ Esta representação de um violento temporal tropical dá realce ao emprêgo de figuras e de contraste, em que Taunay prima. Além disso, o autor ve a natureza com olho de pintor, notando as côres e graduações da aurora e do crepúscu$10,{ }^{37}$ e o tumulto de côres vistas na orilha de uma lagôa. ${ }^{38}$ Nota também, naquêle lugar, o clamor da multidão de pássaros. Existe uma suspensão assustadora na relação da demora do grupo de exploradores, parados na oscuridão, enquanto os irmãos Campos Leite fizeram pesquizas mais adiante. ${ }^{39}$ Oferece-se um contraste admirável entre os sentimentos de um soldado durante a batalha, e a situação patética do ferido. ${ }^{40}$

"A vingança de um recruta" é narrado como se estivesse falando o recruta mesmo. E contado no seu todo em linguagem vernácula, dos lábios de um antigo lavrador gárrulo do interior de Bahia. Cheio de coloquialismos e de termos militares, êste deleitável conto começa: "Ćruz, minha Nossa Senhora da Puríssima Conceição! Vida de recruta é peior que de cachorro magro e sem dono. Parece mesmo que a gente fica mais perrengue do que bicho gafento." "41 Mantem-se a ilusão de que é Tonico que realmente está falando, com um modo de expressão agreste e refrescante: e. g., a sorte de um soldado que se jactou de sua bravura; ${ }^{42}$ a descrição das moças de Montevideo ; 43 etc. Este conto e "O irmão" são as únicas partes do volume 
que contêm uma abundância de coloquialismos. Muitos dos termos que são peculiares ao interior ou ao exército, explicam-se em notas, um procedimento habitual com Taunay.

Com a exceção de "U'm dia de paixão," tôdas as "Narrativas" têm um ambiente realístico de ocurências que tiveram lugar durante campanhas verdadeiras. "O irmão," de certo, é real, menos tal vez o discurso ao começo sôbre o "camarada," que era perito em procurar comida e em confrontar emergências inesperadas. "O capitão caipora" descreve detalhadamente as atividades de uma guarnição militar em tempo de paz, e os males do sistema contemporâneo de promoções militares. ${ }^{44}$ "O Tío Hilário" retrata dois velhos veteranos típicos, com sua vida depois de reformados, e os gracejos dos jovens oficiais, feitos entre si. "A vingança de uma recruta" depende mais na descrição física da atmosfera da vida militar, vista pelos olhos de um recruta ignorante.

Ve-se, às vezes, a personalidade do escritor. A administração militar é condenada por não ter apoiado, e por ter dado ordens, totals à expedição de Matto Grosso. ${ }^{45}$ Os exemplos do sargento Marçal e do capitáo Pitaluga revelaram a necessidade de ter influência no exército para ganhar uma promoção. Os republicanos também são criticados severamente, em "A vingança de um recruta": Tonico disse, ao contar que um grupo de republicanos solicitaram aos soldados que abraçassem os ideais republicanos: "Ora, essa só lembra o diabo! Se iamos dar a vida pelo Império," e "se somos livres, e já se acabou o tempo da tyrannia e dos capitães generaes, também somos monarchistas." 46

Nem sempre, porém, critica Taunay. Está presente, na maioria dos contos, um forte patriotismo. Um exemplo disto é a declaração que as bandeiras e os canhões ainda possuidos pela expedição que se retirou da Laguna, "para essa columna de míseros representavam a única cousa que convinha salvar: a honra." ${ }^{47}$ Também, Tonico disse: "Isto de pátria parece ... uma mentira ou cousa que não existe...; mas.lá chega uma occasião e... surde por causa da pátria no coração da gente uma força tão grande que ninguém póde resistir-lhe." 48

Narrativas militares consta uma mixtura de realidade, de fantasia trivial, e de ficção robustamente realística. Este último componente é a feição saliente do volume. 
Há personagens bem feitos, e passagens descritivas de grande valor, muitas das quais foram republicadas numa obra de maior popularidade, Céus e terras do Brasil.

Geralmente, o interêsse das narrativas seria de um caráter limitado, devido à sua feição militar, mas algumas, como "A vingança de um recruta" e "O Tio Hilário," são excelentes de qualquer ponto de vista, e merecem uma sorte melhor da que têm tido.

\section{"Fantasias"}

Em Céus e terras do Brasil, publicado em 1882, apareceram duas curtas "Fantasias," "O sonho do sabiá" e "A araponga e a onça," que são um produto encantador da imaginação poética de Taunay. Os dois contos têm simplicidade de trama e de fórma, com uma fascinadora atmosfera folclórica. Em "A araponga e a onça," há uma formalidade fingida na apresentação dos "caráteres." O velho pássaro que contou a narração disse: "Tenho bôas razões de ufania por mim e por tôda a nossa illustre grey," e um dos jovens que escutavam era, nos conta o autor, "a mais saidinha do rancho, apezar de viver ainda debaixo das vistas dos seus respeitáveis progenitores." 49 Os dois sanhassús recem-casados não puderam chegar a um acôrdo referente a qual a orilha do rio em que se haviam conhecido, e com isso a fêmea gemeu: "Ah! meus pais! ainda há tão pouco que vos deixei! ... Sou bem infeliz!" e o macho sussurrou: "Preciso condescenter sempre... porque êste delicado entesinho é víctima dos nervos." 50

Em "O sonho do sabiá" há um contraste eficaz na exposição da situação do sabiá, acostumado à liberdade da floresta, e agora encarcelado numa gaióla imunda. No seu sonho, muitas passagens são poetizadas, com uma musicalidade de expressão e imagens poéticas, e. g., a descrição do efeito sôbre a vegetação do sol estival, quando "as árvores contrahiam a folhagem, para darem menor campo aos ráios do desapiedado astro. De prostradas se haviam até calado as cacarejantes seriemas e as estrídulas cigarras." ${ }^{1}$ Diz-se, do oásis no deserto: "alli ciciava uma aragem fresca e insinuante como o hálito da aurora... Nem lhe faltavam as fragrâncias das flôres, pois nos ares se expandiam como borboletas presas por invisiveis fios, odoriferas orchídeas." 52 
Há, nos dois contos, uma atenção de artista à vida, ao movimento, e ao som. O sabiá, cantando da aurora na floresta, "pintou as gradações da luz que vem subindo, o júbilo da terra que acorda, o borborinho da vida em suas primeiras agitações, o chilrar dos insectos, o gazear dos pássaros." 53 A araponga viu um grupo de pássaros que, "Na ramada chilreavam, com mil gorgeios e jovial garrulice, corriam, espanejavam-se, pulavam, brincavam, saracoteavam, ... perseguindo-se uns aos outros, erguendo repentino vôo e ... pousando com grande alarido." 54 A araponga também, falando das suas preparaçōes para espantar a onça, disse: "E continuei sol, si, si; lima, que lima; lima, que lima, rein, rein, rein." ${ }_{55}$ Das passagens que evocam côres vivas, a mais vivida è, tal vez, a descrição do colibri, cujas "refulgentes scentelhas furta-côres ... cambiam, se apagam, rebrilham e fogem, transmudando-se, ora em vivas chispas de fôgo, ora em laminasinhas de ouro esverdeado, prata, cobre ou coruscante aço." 56

As "Fantasias" têm seu lugar distinto entre os contos de Taunay. Têm brilho de côres, estão cheias de movimento e de imagens poéticas, mas ainda o autor as narra com uma simplicidade que nos encanta.

\section{Ao entardecer}

Dos contos de Ao entardecer, "Ciganinha" e "Pobre menino" já foram publicados, sob o pseudónimo "Heitor Malheiros," na Gazeta de Noticias de Rio de Janeiro. "Uma vingança" também foi publicado naquêle jornal, havendo ganho um prêmio para contos anónimos. Todos os contos do volume foram por Taunay reunidos e preparados para serem publicados, com o título tentativo $J a ́$ crepúsculo, mas a morte não the deixou ver a sua publicação. Foram publicados numa edição póstuma, em 1900, com o seu título atual.

Alguns dos contos têm representaçóes excelentes de personagem, e em outros, os caráteres não são de nenhum valor. Em "Pobre menino," por exemplo, há pouco de notável, menos uma vista rápida, em que Taunay se destaca, do pagem que atendeu "Boy."

Por contraste a isso, Gêgéca, a figura principal de "Ciganinha," é bem retratada no seu desenvolvimento desde a menina com modos de rapaz, até a mulher provocativamente bela. Como menina, tinha uma caraterística extraordinária: "No meio de todos êsses desman- 
dos e reparáveis extravagâncias, singular recato, instinctivo e selvático pudor." ${ }^{57}$ Como adolescente, estava completamente sem medo. O conhecimento da sua própria inocência básica lhe fazia desprezar a opinião dos outros, mas o tentado de José Bispo de violá-la, amadureceu-a ensinou-lhe uma bôa lição. Então, sem instrução e sem experiência na sociedade, ainda sabia, por instinto, aplicar os eternos tratagemas femeninos quando apareceu o doutor Anselmo com o coração na mão.

Dona Cula, a mãe de Gêgéca, é um bom retrato de uma sertaneja decadente, vagarosa em pensamento e em ação, indiferente, "falando cantando," e chorando com grande facilidade. A sua falta de espírito apresenta um contraste excelente à vivacidade de Gêgéca. José Bispo era um bruto sensual, dispôsto a violar Gêgéca quando não pôde comprar seus favores. Até the propoz o casamento ao falhar a sua tentativa de violá-la, pensando que a riqueza relativa dêle a faria menosprezar o fato de que êle morava com uma mulher que havia parido quatro dos seus filhos. E o contrário de Anselmo, cuja ufania arrogante se desfez ante a impregnabilidade da virtude de Gêgéca. Ao falharem os seus esforços de seduzi-la com declarações de amor, e até com lágrimas, para casar-se com ela esqueceu a vaidade da família antiga e o medo do que diriam seus pais.

"Cabeça e coração" tenta apresentar o desenvolvimento psicológico dos dois personagens, Bettina e Antenor, especialmente daquêle. Bettina, uma moça formosa, pensava que o respeito que ela tinha para com a profundidade intelectual de Antenor era amor. Não obstante, uma vez casada com êle, não experimentava os sentimentos pelos que suspirava, e caiu nos braços de um homem menos digno, mas mais jovem. Alguns meses mais tarde, ela foi aflita pela compunção, ao apagar-se o fogo da sua paixão ilícita. Antenor, o filósofo, também foi desapontoado por um casamento que invadiu a sua "torre de marfim." Quando Bettina o abandonou, êle sofreu-o com resignação e salvou sua honra com a publicação de uma obra que demostrou a sua propria puridade e honradez. Estes dois não são mais do que perfis de caráteres, e o pouco percebimento psicológico visto na sua revelação não nos impressiona com sua profundidade. O caráter Bettina só serve para ilustrar, mais uma vez, o tema antigo de que a flôr da mocidade tem inevitavelmente de murchar-se ao ser expôsta à geada da velhice. 
"Uma vingança" não tem nenhum esboço de caráter. O único a notar-se é o remorso de Campos pela morte, que êle mesmo causou, de sua esposa, e o ôdio dêle, frio e calculador, para com Sofia, uma típica (para Taunay) borboleta da sociedade que escravizou corações enquanto esperava um casamento que lhe fosse aceitável.

Arnaldo Grácias, de "Rapto original," é um palhaço incomparável: "Dotado de muito chiste natural, talentoso, com estupendo poder de assimilação, sabendo tudo, e no fundo ignorante chapado, verboso, e mais que isso eloquente, com uma phrase viva, faiscante." 58 Dizendo-se descendente de guerreiros espanhóis e amigo de Théophile Gautier, passava seus dias na Rúa do Ouvidor, deixando a seus conhecidos the comprarem o que comer e beber, morando com um grupo após outro de amigos, e tomando prestados dêles dinheiro e roupa. Sempre tinha planos grandiosos, mas nunca levou a cabo nenhum. $O$ único que the molestou quanto a Júlia, a moça frustrada que êle raptou, foi o dinheiro que ela tinha, sendo esta uma comodidade à qual êle nunca tinha dirigido pensamentos sérios. Quando a raptou, o único habitante de Rio de Janeiro que não o sabia de antemão era o pai, vista a incapacidade de Grácias de guardar um segredo.

Não há, no conto, outra pintura real de caráter, menos uma vista breve do velho Candelária, quem se orgulhava de ser polido e civilizado, mas cujo temperamento colérico quasi o conquistou durante uma visita do impertinente Grácias.

Em "O estorvo," Amaro Esteves era um "nouveau-riche" que queria desfazer-se de sua companheira de fazia dezesseis anos, a qual não the convinha mais. Amaro recebe pouca atenção da parte do autor. Quem sobressai, vista pelos olhos de Amaro, é sua mulher, Nicóta, quem não podia adaptar-se à riqueza. Tinha criados em casa, mas todavia se levantava tão cedo como antigamente. Ainda falava com o sotaque carregado e cantado; apenas sabia ler e escrever; e usava os cabelos - sua única feição redentora- puxados para traz, sem atenção à sua pareciência. Sem emoções e escrava dos hábitos, ela, devido à sua fealdade extrema e sua falta de gôsto, despertou em Amaro vergonha dela ao serem êles forçados a sair juntos na sociedade.

Gêgéca e Arnaldo Grácias ficam entre as melhores criaturas de Taunay. Com êsses dois personagens demostra êle a sua capaci- 
dade de criar um vívido retrato físico. Descreve-se Gêgéca com cuidado, nas variadas fases de seu crescimento, e. g., como criança: "esfrangalhada sempré, com as sáias em molambos, o corpete a the cahir pelos hombrinhos magros, descarnados, as pernas à vista, núas, nervosas, esgalgadas, pés no chão." 59 Grácias era "alto, magro, muito claro, com ... cabellos em contínuo desalinho, barba espetada perpendicularmente ao queixo, distinguia-se... por pés e mãos enormes." 60

Do ponto de vista de estilo, existe, em alguns dos contos, uma qualidade notavelmente forçada, certo primor artificial. Um exemplo disto se vê em "Pobre menino," quando a criança olhou o escritor, seus olhos perguntando o que viria após a morte: "Podia confiar?... A leváe-o ... longe, pela immensidade na desconhecida viagem, o regaço de algum anjo, faria vezes da estremecida mãe?" 61 E narrada "Uma vingança," pela mais parte, com simplicidade, mas uma passagem peca por uma superficialidade transparente; $E$ la se foi ella, envolvida nos lânguidos efflúvios de cadenciada e vaporosa música." "62 Todo "Cabeça e coração" é insípido e forçado, por exemplo, Antenor, declarando a Bettina que êle se opunha ao casamento, disse que lhe era difícil dizê-lo: "Imagine abandonada estátua em florido jardim a repellir... o pendão de rosas que busca engrinaldar-lhe a fria e marmórea frente." ${ }^{63} \mathrm{E}$ Bettina, ao conhecer Aguiar, seu futuro amante, sentiu-se inquieta, e aquela noite: "Deitada, só poude conciliar agitados momentos de somno, quando os ráios da aurora acariciaram doce e pallidamente as janellas do seu bello e senhoril palacete de residência." 64

Oferece-se um contraste a esta trivialidade com a expressão robusta das outras narrações. E "pão, pão, queijo, queijo," e recebe-se um impacto impressionante. Em "Ciganinha," Dona Cula foi abandonada por seu amante cigano, e: "Signal da sua passagem, além do volumoso abdomen da Cula, só um cofresinho de bom peso." "ss Gêgéca a menina disse a sua mãe: "Ora, mamãi, de que serviu ... mecê ter sido sempre boa...? O malvado do cigano não lhe fêz mal, não a surrou como boi corneta, e não a deixou de vez com a pança cheia ?" "E6 "Rapto original," Grácias anunciou que o homem devia participar-se dos rigores da reprodução, tão bem como dos prazeres: "Uma vez a esposa, outra o marido. Oa taes senhores que experimentem o que é bom. Quero vêl-os grávidos!" ${ }^{67} \mathrm{Em}$ "O es- 
torvo," a Caxambú : "Certo dia ... à mesa do jantar, Nicóta erguteuse de repente, levou a mão ao peito, soltou um grito abafado de angústia e tombou no chão, redondamente morta." ${ }^{88} \mathrm{E}$ no climax poderoso do mesmo conto, Esteves foi despertado cedo por "mil clarins de Jericó, trompas infernaes, repercussões medonhas, écos terríficos, tudo dominado por uma voz plangente, um uivo de suprema agonia a bradar: Assassino!..." 69

Também há, em dois dos contos, uma destreza agradável de estilo. Narra-se "Ciganinha" num tom de conversa, com termos íntimos e uma atmosfera benévola e familiar. Gêgéca a meina abriu a caixa deixada por seu pai, e "Tratou logo de reduzir a dinheiro um dos collares [que achou], guardando o outro para si ou para maior de espadas." 70 Gêgéca a mulher era tão formosa, que "andava positivamente tonta, de miôlo virado, tôda a rapaziada d'aquêlles centros." " 71 O narrador nos diz, com ironia, que o Dr. Anselmo era descendente do célebre Marquez de São João da Palma, quem "era povoador por excellência. Comprehendia ... que o Brasil ... precisava e ainda precisa de gente, lá, pois, ... applicando com enthusiasmo o multiplicamini de Jehóvah, nem melhores serviços podia prestar à corôa de Portugal." 72 Anselmo, falando com Gêgéca, "se não deitou discurseira, foi por sentir a cabeça que nem um ninho de guaxupés assanhados, debaixo das baterias oculares da ciganinha." ${ }^{73} \mathrm{E}$ no fim o autor escreve: "Entrou por uma porta e sahiu pela outra, e acabouse a história." 74

Todo o conto "Rapto original" foi escrito de um modo humorístico, e, na verdade, é uma gargalhada contínua. É uma sátira admirável dos bobos da sociedade organizada - os que trocam um gracejo por um bocado, um chiste por um refresco, um discurso por uma cama, e que tomam para si, com calma, o que não se thes oferece. Existe, no conto, uma atmosfera divertida de pseudo-gravidade. Júlia, por exemplo, estava "esperando o pretendente patent, garantido pelo governo paternal, quando ferrou n'êsse namoro muito cerrado e sério." 75 Quando o pai de Júlia entrou no quarto de hotel onde Grácias e sua namorada passaram a noite, o noivo, "sentando-se na cama, pegou com as mãos os pés em attitude de quem estava disposto a encetar conversa familiar e entrar em accôrdo amigável." $76 \mathrm{Ha}$, no fim da narração, uma encantadora formalidade fingida. Grácias orgulhava-se de que "Pudera ... sugjugar victorioso 
a animalidade feroz e bramante... e arcar ... com os impetos vorazes da volúpia, tudo para quedar-se immóvel de joelhos, ... na mais adorável e santa vigília de amor e de respeito.” Por isso, êle, Grácias, "em menos de meia hora e entre dous cálices de cognac, compôz, sublimando a virtude própria e o seu heroismo, esplêndido soneto nuns sonóros alexandrinos." 77

Dentre os contos do volume, "Ciganinha" é o mais completamente desenvolvido. Esta chamada "história verdadeira" é autêntica, com una atmosfera convincente de realismo. Empregam-se notas para explicar termos que poderiam despertar dúvidas no leitor, quanto ao seu significado; servem também para estabelecer o fato de que o ambiente foi tirado das observações do escritor, e. g., uma nota sôbre umas quadrinhas cantadas por João Valentim assevera: "Com ligeiras alterações, ouvi tôdas estas quadrinhas da bocca de um d'êsses improvisadores populares." $78 \mathrm{Ha}$, como parte do ambiente realístico do conto, muitos coloquialismos que se empregam no diálogo, o qual tem proeminência, e também fazem parte da narração. Até as descrições da natureza, embóra dêm ênfase, como sempre, às côres e'à forma artística, têm certo sabor coloquial, especialmente na pintura do Rio Paranahyba. ${ }^{79}$

"Uma vingança" e "Cabeça e coração" seguem uma tendência de Taunay o moralizar. O moral do primeiro é que Campos com a vida o que fêz a sua esposa; e Sofia pagou, com a sua reputação, a sua leviandade. A finalidade de "Cabeça e coração" revela-se numa nota: "Foi êste conto resposta à carta de um amigo... que, aos 60 annos, pediu a minha opinião sôbre um casamento desproporcionado, que afinal realisou." ${ }^{80}$ Bettina, culpada primeiro de um raciocínio imprudente, e depois de uma paixão ilícita, sofreu um destino compativel com a sua transgressão social e moral. Uma vez fugida com Aguiar, teve que suportar "as consequências da posição equívoca a que se atirára, mas que o mundo jamais perdôa." Foi mal aconselhada, "já pela cabeça, já pelo coração." 81

"Pobre menino" toca uma refrã que não é comum na produção ficcional de Taunay. $O$ autor, diabético insanável e destinado a morrer, empregou o conto como veículo para filosofar sôbre a morte. Ao primeiro, falou com optimismo, respondendo a "Boy" que êste veria "a realidade, eterna, cheia de encantos e esplendores ... Illimitada é a bondade do immenso Creador!" ${ }^{22}$ Teve, porém, pensamen- 
tos amargos ao ver que o menino falhava; e depois, neútro, o problema não resolvido, depois de que "Boy" foi levado embóra por seus pais, "no vagão vasio, como que continuei a fitar aquêlles olhos ardentes, indagadores, tão suaves, no ingente desespero, na dúvida do problema eterno." 83

Ao entardecer é o último volume da literatura de Taunay. Dá evidência das melhores feições das suas escrituras ficcionais, e. g., desenvolvimento convincente de caráter em alguns casos -invariavelmente quando o ambiente é realístico- e tratamento hábil de cor local. Estabelece uma atmosfera realística como fundo para a intriga de "Ciganinha," que acontece numa vila do interior. Também tem um interessante estilo palestrador e um humor robusto em "Ciganinha," e especialmente em "Rapto original."

Porém, ficam evidentes também alguns dos defeitos habituais de Taunay. Falham seus esforços para a análise psicológica, particularmente em "Cabeça e coração." "Uma vingança" e "O estorvo" não são verdadeiramente psicológicos, mas dependem, por seu efeito, nèste no dito moral que o criminoso não cumpre seus fins, e naquêle numa trama mais ou menos original. Onde o escritor aspira demais a um estilo polido e formal, baseado em raciocínio elaborado e em longos discursos, como em "Cabeça e coração," fica trivial e superficial. "Ciganinha" e "Rapto original" são admiráveis, ao par de qualquer outra escritura de Taunay. Peor do que "Cabeça e coração," a não ser "Um dia de paixão" de Narrativas militares, não escreveu, nem teria podido escrever. "Cabeça e coração," não obstante, junto com "Pobre menino," "Uma vingança," e "O estorvo" sim revela as suas tendências omnipresentes de fazer propaganda e de moralizar.

Nos seus contos, Taunay segue as mesmas inclinações que se percebem nos seus romancẻs. Os seus primeiros contos são em grande parte regionais, baseados nas suas experiências tidas durante a guerra do Paraguay, e nas suas observações, cuidadosamente anotadas, da vida no interior do Brasil. A maioria dos contos são uma refleção do que êle viu e reteve, sendo seu ambiente completamente realístico e os personagens verdadeiros, nos seus pensamentos, nas suas ações, e na sua maneira de falar.

Alguns dos contos que apareceram mais tarde, tais como " $\mathrm{Ca}$ beça e coração," embóra imbuidos de sentimentos sociais, tentam al- 
cançar um estilo refinadíssimo, que as mais vezes não sobrepassa a superficialidade. Outros, como "Uma vingança" e "O estorvo," têm uma simplicidade atraente de expressão. E quando Taunay volta ao seu querido sertão, como em "Ciganinha," e quando escreve num tom de formalidade fingida, como em "Rapto original," êle é magnífico. O fato de que todos êstes últimos contos foram escritos durante mais ou menos o mesmo período de tempo, indica que êle era capaz de produzir material são e divertido, baseado nas suas observações da sociedade carioca - mas que êle escrevia melhor sôbre o interior.

Os contos, no seu todo, revelam também a mesma inclinação que sempre está presente em Taunay - aspira a um alto nivel moral, premia o bom, e pune o mau.

Hubert E. Mate

NOT A S

1 Martin García Mérou, El Brasil intelectual, Buenos Aires, 1901, p. 154. p. 140 .

2 David M. Driver, The Indian in Brazilian Literature, New York, 1942,

3 A. d'E. Taunay, Histórias brazileiras, Rio de Janeiro, 1874, p. 35.

4 Ibid., p. 174.

5 Ibid., p. 18.

6 Ibid., p. 25.

7 Ibid., p. 157.

8 Ibid., p. 23.

9 Ibid., p. 43.

10 Ibtd., p. 36.

11 Ibid., p. 168.

12 Ibid., p. 55.

13 Ibid., pp: 123-124. 
14 Ibid., p. 209.

15 Ibid., 1. 186.

16 Driver, op. cit., p. 140.

17 Ibid.

18 García Mérou, op. cit., p. 154.

19 Entre os nossos indios, São Paulo, 1931, p. 6.

20 Cf. Histórias brazileiras, p. 41, com Entre os nossos indios, pp. 22-23, e Scenas de viagem, Rio de Janeiro, 1868, pp. 174-175.

21 Histórias brazileiras, p. 134 e Entre os nossas indios, p. 28.

22 Histórias brazileiras, pp. 135-136 e Entre os nossos indios, pp. 28-29.

23 Histórias brazileiras, p. 147 e Entre os nossos indios, p. 41.

24 Histórias brazileiras, p. 149 e Entre os nossos indios, p. 42.

25 Histórias brazileiras, pp. 26, 28.

26 Veja-se, e. g., ibid., pp. 185, 188, 189, 204, 221.

27 Ibid., p. 183 ,

28 Veja-se ibid., pp. 24, 29, 148, 190.

29 Veja-se ibid., pp. 43, 162, 165, 177.

30 Dias de guerra e de sertão, São Paulo, 1920, p. 46.

31 Cf. Narrativas militares, Rio de Janeiro, 1878, pp. 9-10, com Céus $e$ terras do Brasil, São Paulo, 1929, yp. 28-29.

32 Narrativas militares, p. 230

33 Ibid., p. 197.

34 Ibid., pp. 208-209, pp. 212-216.

35 Cf. Narrativas militares, p. 43, com Céus e terras, p. 79.

36 Cf., e. g., Narrativas, pp. 54-55, com Céus e terras, pp. 57-58.

37 Narrativas, p. 11.

38 Ibid., p. 44.

39 Ibid., p. 34.

40 Ibid., pp. 63-64. 
41 Ibid., p. 75.

42 Ibid., p. 91.

43 Ibid., p. 100.

44 Taunay mesmo teve uma experiência desilusionante com o sistema, em 1868, sendo passado a favor de um oficial menos qualificado. Veja-se o seu discurso na Câmara dos Deputados, Discurso ... em 14 de abril de 1882, pp. 3031. Veja-se também Memórias do Visconde de Taunay, São Paulo, 1948, p. 443.

45 Narrativas, pp. 17, 19.

46 Ibid., pp. $91,94$.

47 Ibid., p. 66.

48 Ibid., p. 85.

49 Céus e terras do Brasil, p. 96.

50 Ibid., p. 103.

51 Ibid., p. 90.

52 Ibid, p. 92.

53 Ibid.

54 Ibid., pp. 99-100.

55 Ibid., p. 109.

56 Ibid., p. 100.

57 Ao entardecer, Rio de Janeiro, 1900, p. 23.

58 Ibid., p. 157.

59 Ibid., p. 34.

60 Ibid., pp. 159-160.

61 Ibid., p. 26.

62 Ibid., p. 146.

63 Ibid., p. 117.

64 Ibid., p. 128.

65 Ibid., pp. 38-39.

66 Ibid., pp. 42-43.

67 Ibid., p. 162. 
68 Ibid., p. 195.

69 Ibid., p. 196.

70 Ibid., p. 45.

71 Ibid., D. 66.

72 Ibid., pp. 80-81.

73 Ibid., p. 88.

74 Ibid., p. 102.

75 Ibid., pp. 156-157.

76 Ibid., pp. 180-181.

77 Ibid., pp. 182-183.

78 Ibid., p. 70.

79 Ibid., p. 39.

80 Ibid., p. 109.

81 Ibid., p. 134.

82 Ibid, p. 22.

83 Ibid., p. 29. As Memórias de Taunay revelam que êle tinha fé na existência de Deus, mas que, sendo materialista, não dava crédito à religião cristã. Veja-se Memórias, pp. 109-111. 
